[Capper, P. (1992). Curriculum 1991. New Zealand Annual Review of Education, 1, 15-27]

\section{Curriculum 1991}

\section{PHILLIP CAPPER}

$T^{3}$

he year 1991 was one in which the form of new curricula structures and developmental processes began to take shape in every educational sector from pre-school to tertiary. We can say this because it is the first complete year in which the 1989 reforms were operational. We can say no more because the first few years of any new way of doing things represent a shake-down period wherein operational refinements take place, major problems are identified and dealt with, and the real - as opposed to formally defined - power relationships begin to manifest themselves.

To a greater or lesser extent the period 1877-1989 saw steady centralisation and bureaucratisation of curriculum development in every part of the education system. In particular the 1962 Commission on Education ${ }^{1}$ led to the establishment of a significant Curriculum Division in the Department of Education to work in the school and preschool sectors.

The 1989 Act dismantled these structures. Although they had been the subject of considerable criticism on account of their perceived bureaucratic nature, nevertheless the future of curriculum development at the national level was unclear.

Such questions were not ever likely to be answered in 1990, in which the new Act was being implemented and a general election had to occur. Thus it was the Ministry of Education's brief for the incoming government ${ }^{2}$ which took the first analytical look at the new curriculum environment, and attempted to point to future needs.

This briefing correctly identified the fundamental tension between educational needs perceived by the individual student and his or her

\section{Phillip Capper}

family, those perceived at the school community level, and those arising from nationally identified requirements. The report acknowledged that there have been major changes in curriculum policy as a result of the reforms, and noted that this had affected three major dimensions: the way in which schools get curriculum advice and support; the scope of the national curriculum; and the delivery of curriculum development activities. ${ }^{3}$ However it failed to identify the issue which underlies all of the others which is the significant change in the process of curriculum policy development.

In respect of all of these issues the beginning of 1991 was like that moment when one wind has died away, and nobody knows from which direction and with what strength the next one will blow, the only certainty being that it is brewing up somewhere over the horizon.

The reform of educational administration had largely passed curriculum in the schools sector by, not in the sense of leaving structures untouched, but rather in the sense of apparently undervaluing them and dismantling them. Whether this was out of ignorance or by design is a moot point. One argument goes that the reformers did not really understand curriculum processes and held them as being of no account.

But recent history suggests that another view might be more accurate. The 1987 Curriculum Review ${ }^{4}$ was the work of a widely representative group which had held unprecedented consultations with the NZ public. Notwithstanding this it had been vigorously criticised by the Right as being a liberal document out of touch with the needs of the economy. These attacks included a paper prepared by the Treasury for the Minister of Education. ${ }^{5}$ The authors of these criticisms participated in the subsequent programme of administrative reform and it is reasonable to speculate that the dismantling of pre-existing curriculum development structures and processes was a deliberate consequence of Treasury's dissatisfaction with the way in which they had operated.

The vocational, technical, and senior secondary sectors were in a similar limbo, although the administrative provisions were rather different. Whilst the Ministry of Education's curriculum policy functions had been placed more firmly under ministerial control at the same time 
as having its capacity to do development work reduced, the New Zealand Qualifications Authority had evolved not only with the considerable degree of independence which any half-way rational approach to establishing a certificating authority demands, but also with a functional capacity which is probably greater than that possessed by the bodies which preceded it.

It is apparent that the controlling departments of state are not comfortable with this situation, and the appointment of senior personnel with a distinctly liberal tint cannot have made it any better. Nevertheless NZQA is ultimately beholden to the minister and its general policy directions require his approval.

Overall, then, the beginning of 1991 saw national curriculum policy and development more firmly under formal ministerial control than ever before, while in general the capacity of central agencies to facilitate curriculum change at the institutional level had been reduced in the compulsory schools sector, and slightly enhanced in the postcompulsory sector. How the Minister was going to act in this environment remained to be seen.

Similarly how the three changed dimensions identified by the Ministry (delivery of curriculum advice to schools, the scope of the national curriculum, and curriculum development activities) were going to operate in practice was also an unknown.

This lack of attention and the low level of resource application to the curriculum area had led the education community to refer to curriculum in such terms as the "black hole" in the reform process, and in 1990 the PPTA had sought to address this perception by organising a curriculum conference in Christchurch to be held in May 1991, to which it invited a number of eminent overseas educators to deliver keynote speeches. ${ }^{6}$

As it turned out the date of this conference was well chosen. The new Minister spent the first few months of the year coming to grips with his portfolio and sorting out his priorities with his officials. By May he was ready to move on a number of fronts.

\section{The Schools Sector}

The first question concerned the fate of the Curriculum Review. At the beginning of the year the compulsory sector was still governed by the existing core curriculum regulations under the 1962 Act, and an interim curriculum statement from the Ministry which was the first step in the implementation of the Review.

The effect of the new control environment is well illustrated by what subsequently happened. In May the Ministry published a discussion document entitled "The National Curriculum of New Zealand", ${ }_{7}$ and the Minister launched it in his speech to the PPTA Curriculum Conference. 8

The introduction to the discussion document describes an evolutionary process whereby the outcomes of the Curriculum Review, together with the 1990 report Tomorrow's Standards ${ }^{9}$ have been brought together. However both these projects were initiated by the previous Labour Government and the discussion document, especially in that part dealing with the Achievement Initiative, clearly shows that elements of its parentage lie in the 1990 National Party Manifesto.

The complexity of this process was revealed in the way the discussion document was launched. The Christchurch audience listening to the Minister's speech was anticipating something reactionary and rigid, and that is what they seemed to get. The Minister made frequent reference to labour market needs, and a very narrow and functionalist core curriculum. He made no mention of the needs of Maori students or the cultural and social aspects of schooling, and he received a hostile response.

However when attendees read the document itself, they found something which really did demonstrate a broader conception of what a school curriculum ought to be. The final verdict on it was reasonably positive, although substantial concern remained about the ill-developed concept of "technology" in the curriculum, and the implications of across the board testing contained in the section on the Achievement Initiative.

Observers concluded that the differences between the Minister's speech and the actual emphases of the discussion document indicated 
an unresolved debate between the Minister and his advisers and a clear signal as to the Minister's own priorities. This latter perception was soon confirmed by the Minister's rapid allocation of resources to the development of Achievement Initiative orientated syllabus statements in English and Mathematics.

The strength of ministerial influence has been further demonstrated by the process by which the new statements on Mathematics, Science, and English (in that order) have been produced. Working at breakneck speed to satisfy political timetables, the memberships of the various working parties have also been strongly influenced by the Minister's personal views.

The Mathematics committee, for example, was initially strongly criticised by the Minister on the sound premise that there were too many academics and not enough teachers on it. However when this was corrected by replacing some of the academics with teachers, the practitioners came predominantly from Auckland schools serving predominantly white upper middle class areas.

Although in the example described, the resulting proposals have been welcomed with cautious affirmation, the fact remains that syllabus committees now represent nobody except the preconceptions of the minister of the day. In the long run there must be serious doubt about the capacity of such groups to produce curriculum statements which can stimulate the necessary magic of teacher ownership and stable evolutionary curriculum development.

Strangely enough it has also transpired that the ministerially handpicked working parties and committees have been inclined to produce reports more politically embarrassing for the government than did those representative groups which preceded them. While in practice they have produced quite measured curriculum statements, they have also included resource demands to a level which the old representative groups - peopled by politically sophisticated pragmatists - would have certainly concluded to be excessive. Nobody knew better than teacher union participants in curriculum development exercises that a sure way to have a report sink without trace, was to include resource demands which were quite clearly beyond the capacity of current fiscal realities to provide.

An example to demonstrate this point was the Ministerial Working Party on Science and Technology Education Report, ${ }^{10}$ worked on in 1991 but only released in February, 1992. The Working Party consisted of research scientists from the public, private, and university sectors, together with school teachers carefully screened for their lack of teacher union activism, leavened with a couple of private sector businessmen.

Despite its careful selection, the Working Party has produced a report which will embarrass the Minister, containing as it does not only statements about the general level of employer satisfaction with what the education system is providing, and assertions about the need to integrate elements such as interpersonal skills into Science and Technology education which come straight out of the much maligned 1987 Curriculum Review; but also contains very resource hungry recommendations in respect of teacher development, and calls for tagged funding for schools - a notion which is an absolute anathema in the new devolved administrative environment.

However by the end of the year it had become apparent that while curriculum generated demands for resources probably doom the reports that contain them to oblivion in the present environment, to everyone's surprise, measured curriculum statements bearing strong echoes of a liberal past are not necessarily going to be rejected by the present Minister.

While there must always be questions about any process which is based so firmly in the attitudes of the Minister, regardless of what the qualities of any particular incumbent may be, Dr Smith himself has put in an unexpectedly good performance in 1991, and has won increasing, if sometimes grudging, respect for his curriculum decisions. It is clear that he has listened carefully to his advisers, has modified his views in the light of arguments he has heard, and has gained respect amongst many he has worked with for the sincerity of his desire to assist underachievers. Historically, education ministers who amend their views in the light of exposure to the views of educators tend to be regarded by 
their colleagues as having been "captured", but whatever his fate turns out to be, Dr Smith has certainly proved more open to the influence of well-presented arguments than his detractors expected.

In particular he has observed the problems England has had with across the board testing, has talked to his officials, and has consequentially amended policy on schools testing towards the entirely sensible model of providing teachers with diagnostic instruments which they can use voluntarily as a developmental tool for their own students.

However a review of formal and informal statements by ministry officials indicates that the Achievement Initiative as a centrally driven policy remains above all a device for assisting in the targeting of funding, a purpose which must eventually bring conflict with the educationally sound rhetoric which is currently being attached to the exercise.

At the year's end a number of major problems in curriculum development in the schools sector remain unresolved. All curriculum statements eventually come to naught if teachers do not change their practice. Furthermore the best formalised curriculum change is based on existing best practice which tabulates what leading teachers are already doing.

Hence timely curriculum change of high quality depends on there being an intelligence network which is observing and collecting data on current best practice, and which can also disseminate models of excellence throughout the system.

The capacity to do these things does not currently exist. The Education Review Office is specifically precluded from indulging in the word of mouth dissemination of observed excellent practice which the old inspectorate did so effectively, and there is no other body capable of doing it. Central curriculum committees now have very little to go on except the personal experience of participants, and must become impoverished as a result. Finally with tagged funding unacceptable it has become extremely difficult to ensure that curriculum change can be facilitated through teacher development because it is not possible to require boards of trustees to spend their funding on particular activities.
Indeed there are increasing signs that a significant number of boards are diverting teacher development funds into other activities altogether.

In fact the whole question of the role of boards of trustees and local school management in the making of curriculum decisions is fraught in the new administrative environment. A significant part of the Tomorrow's Schools rhetoric concerned the assertion that parents know what is best for their own children, and that this extends to the curriculum.

In reality they do not. Nor do individual teachers, nor individual employers. In fact it is very difficult indeed for even the best informed to predict what curriculum will best serve today's students. The best curriculum decisions are those which arise from painstaking discussion between all the stakeholders, and are implemented by authorities which have sufficient control over the disposition of resources to ensure that teachers are retrained to deliver the new syllabuses.

In the areas of ethical and social education there is no doubt that parents must have a dominant say, but parents are probably the least competent of all stakeholders to establish what skills, competencies and knowledge their children are going to need in order to participate productively in tomorrow's economy.

The 1989 Education Act did recognise this and established a role for local and central agencies in determining the curriculum. But how these competing perceptions and interests are to be balanced out in the decision making process remains unresolved. It must not remain so for too much longer.

\section{The Post Compulsory and Tertiary Sectors}

In 1991 the post-compulsory and tertiary sectors saw the emergence of a plan which, if implemented in its suggested form - and this now seems likely - will produce an educational revolution which has intended and unintended components.

In March, two months before the release of the discussion paper on the National Curriculum, the New Zealand Qualifications Authority produced its own discussion document Designing the Framework. ${ }^{11}$ Public 
responses were invited up until August, and the large number received seem to have ensured that the proposal will be broadly implemented. The key to NZQA's framework proposal is the National Certificate. It will be, according to the discussion document:

... a co-ordinated set of units of learning, available to students at senior secondary school, in polytechnics, colleges of education, universities or private training establishments, and in wananga, marae, or community agencies. Such learning must be equally available at the workplace, and through self-directed study or experiential learning.

This proposition is much more ambitious in its scope than the Scottish SCOTVEC model on which it is based. It arises from the call for greater relevance, flexibility, and capacity for frequent retraining in the field of vocational education. In New Zealand, as in Scotland, the original conception leaves in place the more traditional certification path which leads towards academic higher education.

However it is already becoming apparent in Scotland that once this sort of certification is in place the distinction between the academic and vocational tracks in post-compulsory education immediately begins to blur. It is reasonable to assume that such a process will be even more rapid under the NZQA proposals, as the definition quoted above already includes higher education establishments in the framework.

The whole has the potential of inducing a major social revolution in which access to learning and certification becomes democratised as never before. It is ironic that here, as elsewhere, such a revolution should be triggered unwittingly by right wing governments whose main motivation is to produce a more highly skilled workforce.

The availability of such a curriculum delivery and certification system in the senior secondary schools, and the legitimation of the recognition of experiential learning within the formal certification system, also produces a revolutionary shift in the relationship between students, teachers and the institutions. Units of learning assessed by standards based criteria in which the standards to be attained are clearly stated in the unit statements, empower the student by providing them with information not always available in traditional settings. When the capacity to recognise and accredit prior and experiential learning is added, thereby by-passing traditional attendance pre-requisites, the student becomes very much a person obtaining a service, and ceases to be an acolyte proving him or herself to the shaman-like teacher.

Such role shifts will require teachers at all post-compulsory levels, but especially in the senior secondary school, to rethink the way in which they do their jobs. The fact that models of the nature proposed in Designing the Framework produce the first fundamental conceptual shift in education delivery in more than a century, did not seem to have been recognised by the education community at large by the end of 1991, even though this was seven months after the release of the document. This is of concern, because major realignment of teacher attitudes will have to be undertaken through retraining programmes if the National Certificate is to succeed.

But the latent impact of the National Certificate does not merely reside in the attitudes of personnel. It will also see major reorganisation of institutions and their management. A real problem can be predicted here. The system has just gone through a major organisational reform, but one which was predicated on traditional models of educational delivery. As a consequence there is a great weariness amongst teachers which has left them averse to the prospect of further change at the very moment when unprecedented changes which will alter their day to day classroom environment are about to engulf them.

The National Certificate framework requires yet more rethinking. Timetabling has to change, together with daily and annual organisation. New jobs emerge, for instance to carry out the process of evaluating claims for experiential credit. The relationships between institutions alters. Universities in particular will be compelled to reappraise the relationship of their courses to the offerings of other tertiary institutions.

Overall educational institutions are, despite popular perception, remarkably responsive to the needs of their students, even though such responses are often intuitive in the absence of any analysis of the social environment they are responding to. However intuitive responses are 
by their nature reactive, and the potential impact of the National Certificate requires forward planning on an unprecedented scale. Such planning was not in evidence by the end of 1991.

Nevertheless educational institutions are already reacting to community trends to which NZQA's framework will eventually represent the formal and organised response. Schools are introducing "Form $8 \mathrm{~s}$ ", and some are working hard at modular reorganisation of their curriculum.

Even now some schools are slipping into offering tertiary courses to the extent that by year's end the Ministry of Education was developing an ad hoc response for 1992 to tide them over until a more formal policy can be developed for $1992 .{ }^{12}$ This response is essentially to accept that schools can do whatever they want in the field of tertiary offerings, and compete with tertiary institutions if they wish. While this is logical in terms of the ideals of the framework, it leaves major long term questions of resource allocation, funding, overall policy control, and institutional organisation.

\section{Conclusions}

All of these reforms illustrate the complex relationships between curriculum content, assessment and certification, educational administration, and societal values. The framework suggested by NZQA has been made possible by technical advances in assessment methodology and have in turn allowed curriculum developers to think in new and less constrained ways about their work. The outcomes are likely to be further substantial change in institutional administration and management, with the whole effecting a social revolution in terms of access to knowledge and credentials.

However the economic context in which all this is happening creates a paradox. The driving force for these reforms has been the desire to assist in making an ailing nation "internationally competitive" by enhancing the skills base of its population. But the very same economic problems have resulted in a squeeze on public funding for education. So while post compulsory curriculum and assessment is being reformed to facilitate broad based accessibility, actual access to courses, especially in the university sector, is becoming increasingly restricted because of financial constraints. At the end of 1991 this remained an unresolved paradox and a challenge for future policy.

In terms of actual curriculum design the year ended with a definite shift in central policy thinking away from the very narrow definitions of basic and vocational education of the beginning of the year towards broader conceptions which are developmentally closer to the proposals of the 1987 Curriculum Review.

In 1990 Ivan Snook observed that the "... the score in recent years is nil-all: neither Wellington's "conservative" curriculum nor Marshall's "liberal" one has been implemented." ${ }^{13}$ Using Snook's labels Lockwood Smith's curriculum is shaping up to have a "conservative" rhetoric and a "liberal" structure; an indication, perhaps, that the schools of thought that the labels define generate more heat in public debate than actual differences in curriculum content.

The 1991 discussion papers may come to be regarded as a turning point in New Zealand education policy at least in terms of pedagogical method; but in terms of curriculum content, history is now more likely to see them as part of a developmental continuum than as a radical break with the directions of the previous forty years.

\section{Notes}

1 Department of Education, Report of the Commission on Education in New Zealand. Wellington: NZ Government Printer, 1962.

2 Ministry of Education, Quality Education for All According to Their Needs. Wellington: NZ Government Printer, 1990.

3 Ministry of Education, 1990, ibid, p. 49

4 Department of Education, Report of the Committee to Review the Curriculum for Schools. Wellington: NZ Government Printer, 1990.

5 For a summary see Codd, J. Education Policy and the State in Middleton, Codd, and Jones (Eds.) New Zealand Education Policy Today. Wellington: Allen and Unwin, 1990.

6 Capper, P. (Ed.) Curriculum Conference 1991, Proceedings. Wellington: NZPPTA, 1991. 
7 Ministry of Education, The National Curriculum of New Zealand, A Discussion Document. Wellington: Learning Media, 1991.

8 Capper, P. (Ed.), 1991,ibid, pp. 66-71

9 Ministry of Education, Tomorrow's Standards, The Report of the Ministerial Working Party on Assessment for Better Learning. Wellington: Learning Media, 1990.

10 Ministry of Education and Ministry of Research, Science and Technology, Charting the Course, Report of the Ministerial Task Group Reviewing Science and Technology Education. Wellington: Learning Media,1992.

11 New Zealand Qualifications Authority Designing the Framework. Wellington: NZQA, 1991.

12 Ministry of Education, School/Tertiary Interface in 1992: Discussion Paper. Unpublished internal paper, Wellington.

13 Snook, I. Contesting the Curriculum: The Politics of Basics and Frills in Codd, Harker and Nash (Eds.) Political Issues in New Zealand Education, Palmerston North: Dunmore Press, 1990, p. 318.

\section{The author}

Phillip Capper is an Advisory Officer with the Post Primary Teachers' Association and a former secondary school teacher. He has published widely on education topics and has given papers in NZ, Australia, USA, England and Finland. He also publishes fiction and poetry. 